\title{
Stimulation of Cytokine Gene Expression in a Murine Macrophage Cell Line by Lactic Acid Bacteria Isolated from Bhutanese Dried Yak Cheese
}

\author{
Yuji OHAShI ${ }^{1}$, Kanako Nagal ${ }^{1}$, Makoto Tokunaga ${ }^{1}$, Kazunari UshidA ${ }^{1, *}$ and Tomomi Yamada ${ }^{2}$ \\ ${ }^{1}$ Laboratory of Animal Science, Kyoto Prefectural University, Shimogamo, Kyoto 606-8522, Japan \\ 2 Institute of Low Temperature Science, Hokkaido University, Sapporo, Hokkaido 060-0819, Japan
}

Received May 16, 2005; Accepted for publication, September 10, 2005

Lactic acid bacteria (LAB) isolated from dried yak cheese from the Bhutan Himalayas were examined for their ability to stimulate the expression of cytokine mRNA on the murine macrophage. The expression of tumor necrosis factor- $\alpha$, interleukin (IL) 6 or IL-12 p40 gene was stimulated by several strains. The dried yak cheese, Chugo, contains LAB that possess immuno-modulating activity.

Key words: lactic acid bacteria; cytokine; macrophage; fermented food

Lactic acid bacteria (LAB) are found in various fermented foods, and their beneficial effects on human health and livestock animals have been stressed (12). Among them, stimulation of the mucosal immune system is one of the most beneficial functions of lactic acid bacteria. A wide range of lactobacilli can stimulate macrophages to secrete pro-inflammatory cytokines which are responsible for the enhancement of the mucosal immune system $(4,11,14)$. Many traditional fermented foods that contain LAB are available in Asian countries, and these foods may have beneficial effects on health. Many LAB have been isolated from the cheeses available in Asian countries (2, 3, 9, 20). However, their immunological effects have not been examined in detail. In this study, we isolated LAB from Chugo, dried yak cheese, donated or purchased from the local people of northwestern Bhutan, mainly in the Lunana area, and examined their ability to stimulate cytokine production by murine macrophages in vitro. Over 100 strains of LAB were isolated from 13 samples of Chugo cheese. A portion ( 0.2 to $0.5 \mathrm{~g}$ ) of the cheese was suspended in $10 \mathrm{ml}$ of phosphate buffer $(50 \mathrm{mM}$, pH 7.5) and inoculated to LBS (Becton, Dickinson and Company, Cockeysville, MD, USA) and MRS (Becton, Dickinson and Company, Sparks, MD) agar plates. These media were incubated at $37^{\circ} \mathrm{C}$ under aerobic and anaerobic conditions. Twelve rod-shaped bacteria were selected from 108 isolates and divided into 4 groups according to their morphology and tolerance to oxygen. One strain was randomly selected from each group.

*Corresponding author. Mailing address: Laboratory of Animal Science, Kyoto Prefectural University, Shimogamo, Kyoto 606-8522, Japan. Phone and Fax: +81-75-703-5620. E-mail: k_ushida@kpu.ac.jp
Four selected LAB were incubated in MRS broth at $37^{\circ} \mathrm{C}$. After the collection of bacterial cells, a portion was used for DNA extraction (21). The 16S rDNA was amplified by polymerase chain reaction (PCR) with primers $907 \mathrm{f}\left(5^{\prime}\right.$-AAACTCAAATGAATTGACGGG3') and univ-R (5'-ACGGGCGGTGTGTACAAG-3') with $r$ Taq polymerase (TOYOBO, Tokyo, JAPAN). The PCR products were sequenced with an LI-COR autosequencer (LIC-4200L; Aloka, Tokyo) using a Thermo Sequenase Cycle Sequencing Kit (Amersham Pharmacia Biotech, Tokyo). The obtained sequences were subjected to a BLAST search with known sequences in the GenBank.

The rest of the bacterial cells were washed and suspended in phosphate buffered saline (PBS) to obtain $10^{8}$ cells $/ \mathrm{ml}$. Then they were heat inactivated at $100^{\circ} \mathrm{C}$ for $10 \mathrm{~min}$. The RAW 264.7 murine macrophage cell line was maintained in RPMI 1640 medium (Sigma, St. Louis, MO, USA) supplemented with $10 \%$ (v/v) heatinactivated fetal calf serum (Biological Industries, Kibbutz Beit Haemek, ISRAEL), $50 \mu \mathrm{M} 2$ mercaptoethanol, $1 \mathrm{mM}$ HEPES, $100 \mathrm{U} / \mathrm{ml}$ penicillin, and $100 \mathrm{mg} / \mathrm{ml}$ streptomycin at $37^{\circ} \mathrm{C}$ in $5 \% \mathrm{CO}_{2}$. Cultivated macrophages were spread onto a 24 -well flatbottomed plate with $6 \times 10^{5}$ cells $/ 2 \mathrm{ml} /$ well in fresh medium. Then, $100 \mu \mathrm{l}$ of the heat-inactivated bacterial suspension was added to each well. For the control, 100 $\mu l$ of the sterilized PBS was added to each well instead of the bacterial suspension. After $24 \mathrm{~h}$ incubation at $37^{\circ} \mathrm{C}$ in $5 \% \mathrm{CO}_{2}$, total RNA was extracted from the macrophages with ToTALLY RNA Kit (Ambion, Austin, TX, USA) according to the manufacturer's directions. Total RNA (100 ng) was applied to the 
Table 1. Isolated lactic acid bacteria from Bhutanese dried yak cheese

\begin{tabular}{lccll}
\hline Strain & Medium & Facultative/obligate & Shape & Closest relative \\
\hline $28-2$ & LBS & Facultative & Rod & \\
$28-2-2^{*}$ & LBS & Facultative & Rod & L.parakefiri \\
$12115-15$ & LBS & Facultative & Rod & \\
$1219-03^{*}$ & LBS & Obligate & Rod & L.plantarum \\
$1219-09$ & LBS & Obligate & Rod & \\
$1219-12$ & MRS & Obligate & Rod & \\
$1219-21$ & LBS & Obligate & Rod & \\
$0108-1^{*}$ & LBS & Obligate & Long rod & L.paracasei \\
$0108-2-2$ & LBS & Obligate & Long rod & \\
$0108-4$ & LBS & Obligate & Long rod & \\
$0108-4-2$ & LBS & Obligate & Long rod & \\
$1211-06^{*}$ & MRS & Facultative & Short rod & Leuconostoc sp. \\
\hline
\end{tabular}

*Strains which were used for identification and in vitro experiments with the murine macrophage cell line RAW 264.7.

reverse transcription-PCR (RT-PCR) with TaKaRa RNA PCR Kit Ver. 3.0 (Takara Bio, Kyoto, JAPAN). Reverse transcription was performed with Oligo dT primer at $60^{\circ} \mathrm{C}$ for $30 \mathrm{~min}$. The primers for glyceraldehyde 3-phoshate dehydrogenase (G3PDH) (5' TGAAGGTCGGTGTGAACGGATTTGGC-3' and 5'CATGTAGGCCATGAGGTCCACCAC-3'), IL-6 (5'ATGAAGTTCCTCTCTGCAAGAGACT-3' and 5'CACTAGGTTTGCCGAGTAGATAT-3'), TNF- $\alpha$ (5'TTCTGTCTACTGAACTTCGGGGTGATCGGTCC-3' and 5'-GTATGAGATAGCAAATCGGCTGACGG TGTGGG-3'), and IL-12 p40 (5'-CCA CTCACATCTGCTGCTCCACAAG-3' and 5'ACTTCTCATAGTCCCTTTGGTCCAG-3') used for the PCR, were purchased from Clontech (Palo Alto, CA, USA). The PCR was performed with a temperature program of $3 \mathrm{~min}$ at $94^{\circ} \mathrm{C} ; 30$ cycles of $20 \mathrm{~s}$ at $94^{\circ} \mathrm{C}, 45 \mathrm{~s}$ at $60^{\circ} \mathrm{C}$, and $1 \mathrm{~min}$ at $72^{\circ} \mathrm{C}$; followed by extension for 5 min at $72^{\circ} \mathrm{C}$. After the PCR products were electrophoresed, the bands were quantified with NIH Image (National Institute of Health, Bethesda, MD). The density of each mRNA band was normalized to that of G3PDH. The results were expressed as means with standard deviations of three independent experiments. The differences between the values obtained with and without cell suspension were statistically analyzed by a Boneferroni/Dunn analysis after one-way ANOVA.

Twelve strains of rod-shaped LAB were selected (Table 1). The partial sequences of $16 \mathrm{~S}$ rDNA (containing V6, V7, and V8 regions) retrieved from strains 28-2-2, 0108-1, 1211-06, and 1219-03 were similar to those of L.parakefiri [GenBank accession number AY026750, 98\% similarity], L.paracasei [AJ271854, 97\% similarity], Leuconostoc sp.
[AF349931, 98\% similarity], and L.plantarum [AJ272031, 95\% similarity], respectively. The strain 1211-06 significantly stimulated the expression of TNF$\alpha$, and strain 0108-1 stimulated the expression of IL-6 and IL-12 p40 genes in murine macrophages (Fig. 1). The level of mRNA was determined to investigate the cytokine production, since cytokine production at the protein level reflects the expression of the cytokine gene (6-8). Consequently the strain 1211-06 stimulated TNF$\alpha$ production, and the strain $0108-1$ stimulated IL- 6 and IL-12 p 40 production. TNF- $\alpha$ production by macrophages is one of the anti-tumor characteristics of lactobacilli (11). Therefore, strain 1211-06 may have the potential to inhibit tumor growth.

Strain 0180-1 stimulated expression the of IL-12 p40 and IL-6 genes. Many probiotic lactobacilli have been reported to enhance IL-12 and IL-6 production (4, 14, 19). IL-12 induces the proliferation of Th1 cells $(10,18)$. Induction of a Th1-type immune response is critical for the prevention and treatment of type- 1 allergenic diseases in which Th2-type immune responses exceed those of the Th1 type (1). IL-6 promotes differentiation of $B$ cells into plasma cells and enhances the secretion of $\operatorname{IgA}(3,13,17)$. In addition, IL-6 polarizes naïve $\mathrm{CD} 4^{+} \mathrm{T}$ cells transforming them to effecter Th2 type cells (16). Furthermore, IL-6 activates pathogen specific activity with block of the suppressive activity of CD4 ${ }^{+} \mathrm{CD} 25^{+} \mathrm{T}_{\mathrm{R}}$ cells (15). Therefore, the strain 0180-1 may modulate the host immune system through the stimulation of cytokine production of antigen present cells, such as macrophages and dendritic cells.

Although the identification of LAB in this study was incomplete, the dried yak cheese, Chugo, contains LAB that possess immuno-modulating activities. 


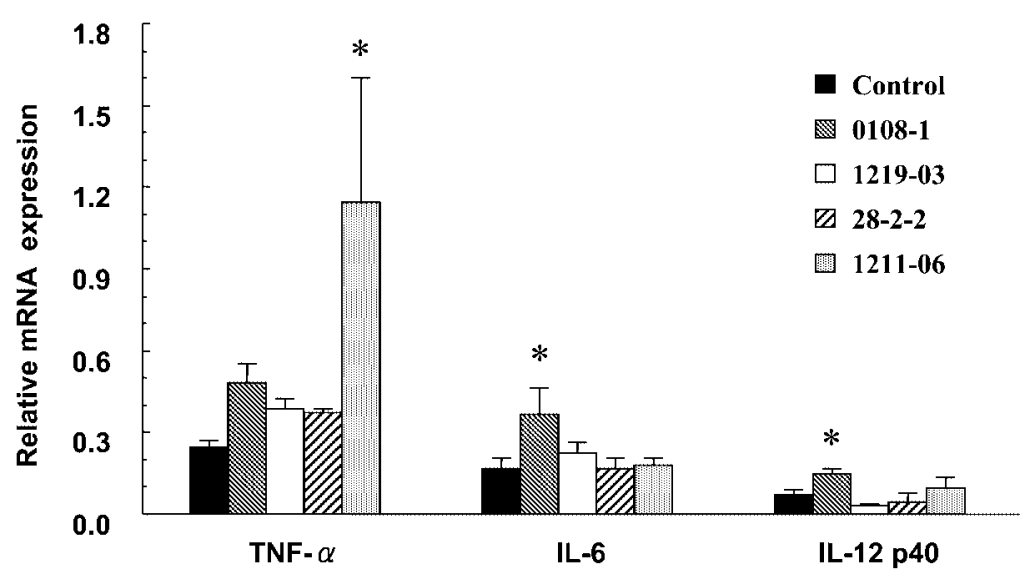

Fig. 1. The mRNA expression of cytokines in the murine macrophage cell line RAW 264.7 cultured with lactic acid bacteria isolated from Bhutanese dried yak cheese. Total RNA was extracted from cells, and RT-PCR was performed. The quantification of each PCR product was performed by the method described in the text. The results were expressed by means and standard deviations of three independent experiments. *Values significantly different $(p<0.05)$ from control.

Acknowledgments. A part of this study was supported by a Grant-in-Aid for Scientific Research (B) 13573004 from the Japan Society for Promotion of Science. For the collection of dried yak cheese, we are indebted to Mr. Karma, Mr. Indra K. Chhetri, and Mr. Lobzang Gyenden (Geological Survey of Bhutan, Royal Government of Bhutan), and Mr. Jai Narayan Sharma (Ministry of Agriculture, Royal Government of Bhutan). We also thank Dr. Satoshi Matsumoto (Yakult Central Institute for Microbiological Research) for his kind donation of the murine macrophage cell line, RAW 264.7.

\section{REFERENCES}

(1) Brandtzaeg P. 2002. Current understanding of gastrointestinal immunoregulation and its relation to food allergy. Ann NY Acad Sci 964: 13-45.

(2) Bulut C, Gunes H, Okuklu B, Harsa S, Kilic S, Coban HS, Yenidunya AF. 2005. Homofermentative lactic acid bacteria of a traditional cheese, Comlek peyniri from Cappadocia region. J Dairy Res 72: 19-24.

(3) Durlu-Ozkaya F, Xanthopoulus V, Tunail N, Litopoulou-Tzanetaki E. 2001. Technologically important properties of lactic acid bacteria isolates from Beyaz cheese made from raw ewe's milk. J Appl Microbiol 91: 861-870.

(4) Erickson KL, Hubbard NE. 2000. Probiotic immunomodulation in health and disease. J Nutr 130: 403S-409S.

(5) Fagarasan S, Honjo T. 2003. Intestinal IgA synthesis: regulation of front-line body defences. Nature Rev Immunol 3: 63-72.

(6) Fiorucci S, Distrutti E, Mencarelli A, Barbanti M,
Palazzini E, Morelli A. 2002. Inhibition of intestinal bacterial translocation with rifaximin modulates lamina propria monocytic cells reactivity and protects against inflammation in a rodent model of colitis. Digestion 66: 246-256.

(7) Hirata I, Murano M, Nitta M, Sasaki S, Toshina K, Maemura K, Katsu K. 2001. Estimation of mucosal inflammatory mediators in rat DSS-induced colitis. Digestion 63 (suppl 1): 73-80.

(8) Issacs KL, Sarot RB, Haskill S. 1992. Cytokine messenger RNA profiles in inflammatory bowel disease mucosa detected by polymerase chain reaction amplification. Gastroenterology 103: 1587-1597.

(9) Kivanc M. 1989. Asurvey on the microbiological quality of various cheeses in Turkey. Int J Food Microbiol 9: 73-77.

(10) Neurath MF, Finotto S, Glimcher LH. 2002. The role of Th1/Th2 polarization in mucosal immunity. Nature Med 8: 567-573.

(11) Maassen CBM, van Holten-Neelen C, Balk F, Heijne den Bak-Glashouwer J, Leer RJ, Laman JD, Boersma WJA, Claassen E. 2000. Strain-dependent induction of cytokine profiles in the gut by orally administered Lactobacillus strains. Vaccine 18: 2613-2623.

(12) Macfarlane GT, Cummings JH. 1999. Probiotics and prebiotics: can regulating the activities of intestinal bacteria benefit health? Br Med J 318: 999-1003.

(13) Macpherson A, Hunziker L, McCoy K, Lamarre A. 2001. IgA respomces in the intestinal mucosa against pathogenic and non-pathogenic microorganisms. Microbes Infect 3: 1021-1035.

(14) Morita H, He F, Fuse T, Ouwehand AC, Hashimoto H, Hosoda K, Mizumachi H, Kurisaki J. 2002. Cytokine production by the murine macrophage cell line J774.1 
after exposure to lactobacilli. Biosci Biotechnol Biochem 66: 1963-1966.

(15) Pasare C, Medzhitov R. 2003. Toll pathway-dependent blockade of $\mathrm{CD} 4{ }^{+} \mathrm{CD} 25^{+} \mathrm{T}$ cell-mediated suppression by dendritic cells. Science 299: 1033-1036.

(16) Ricon M, Anguita J, Nakamura T, Fikrig E, Flavell RA. 1997. Interleckin (IL)-6 directs the differentiation of IL-4-producing CD4 ${ }^{+}$T cells. J Exp Med 185: 461469.

(17) Sato A, Hashiguchi M, Toda E, Iwasaki A, Hachimura S, Kaminogawa S. 2003. CD $11 b^{+}$peyer's patch dendritic cells secrete IL- 6 and induce IgA secretion from naive B cells. J Immunol 171: 3684-3690.

(18) Trinchieri G. 1994. Interleukin-12: a cytokine produced by antigen-presenting cells with immunoregulatory functions in the generation of $\mathrm{T}$ helper cells type 1 and cytotoxic lymphocytes. Blood 84: 4008-4027.

(19) Vaarala O. 2003. Immunological effects of probiotics with special reference to lactobacilli. Clin Exp Allergy 33: $1634-1640$

(20) Zhang XB, Ohta Y, Hosono A. 1990. Antimutagenecity and binding of lactic acid bacteria from a Chinese cheese to mutagenic pyrolyzates. J Dairy Sci 73: 2702-2710.

(21) Zhu H, Qu F, Zhu LH. 1993. Isolation of genomic DNAs from plants, fungi, and bacteria using benzyl chloride. Nucleic Acids Res 21: 5279-5280. 